\title{
Emerging Roles of BRD7 in Pathophysiology
}

\author{
Sang Won Park $1,2, * \mathbb{D}$ and Junsik M. Lee ${ }^{1}$ \\ 1 Division of Endocrinology, Boston Children's Hospital, Boston, MA 02115, USA; \\ junsik.lee@childrens.harvard.edu \\ 2 Department of Pediatrics, Harvard Medical School, Boston, MA 02115, USA \\ * Correspondence: sangwon.park@childrens.harvard.edu
}

Received: 7 September 2020; Accepted: 23 September 2020; Published: 27 September 2020

\begin{abstract}
Bromodomain is a conserved structural module found in many chromatin-associated proteins. Bromodomain-containing protein 7 (BRD7) is a member of the bromodomain-containing protein family, and was discovered two decades ago as a protein that is downregulated in nasopharyngeal carcinoma. Since then, BRD7 has been implicated in a variety of cellular processes, including chromatin remodeling, transcriptional regulation, and cell cycle progression. Decreased BRD7 activity underlies the pathophysiological properties of various diseases in different organs. BRD7 plays an important role in the pathogenesis of many cancers and, more recently, its roles in the regulation of metabolism and obesity have also been highlighted. Here, we review the involvement of BRD7 in a variety of pathophysiological conditions, with a focus on glucose homeostasis, obesity, and cancer.
\end{abstract}

Keywords: BRD7; glucose metabolism; type 2 diabetes; XBP1s; PI3K; p85; cancer

\section{Introduction}

Bromodomain is an evolutionarily conserved module, which consists of 110 amino acids [1,2]. It recognizes acetylated lysine residues through its hydrophobic cavity formed by four $\alpha$-helices and two loops, and modulates the activity of other proteins [1,3-5]. The first protein reported to contain bromodomain was the Brahma protein, a regulator of Drosophila homeotic genes [6]. Since then, more than 60 different bromodomain sequences have been identified that can be categorized into 8 different families, based on structural similarities [7]. Bromodomain is found in a wide range of proteins and in most tissues, including metabolic, nervous, reproductive, and connective tissues [8,9]. Bromodomain-containing proteins serve critical roles in a variety of activities such as chromatin remodeling [10,11], transcriptional regulation [5], and cell signaling [9].

Bromodomain-containing protein 7 (BRD7) was first identified as a $75 \mathrm{kDa}$ protein that interacts with the mouse protein tyrosine phosphatase BAS-like (PTP-BL) protein [12]. BRD7 is found in various tissues, including the lung, heart, muscle, kidney, brain, thymus, pancreas, skin, testes, liver, and colon [12], and is expressed at all stages of life, from fetus to adulthood [8,9]. Mice that lack BRD7 die by gestational day 16.5 [13], underscoring the protein's crucial role during embryonic development. BRD7 binds to acetylated histones through its bromodomain and regulates transcription of cell cycle genes [14,15]. BRD7 is also a component of polybromo-associated BRG1-associated factor (PBAF), an ATP-dependent chromatin remodeling complex that is an analogue of the SWItch/Sucrose Non-Fermentable (SWI/SNF) complex [16]; it thus additionally modulates the transcription of genes as a regulator of SWI/SNF. Furthermore, BRD7 participates in the cell cycle, apoptosis, and cell progression (Table 1). Here, we review the role of BRD7 in a variety of clinical conditions (Table 2), with a focus on glucose metabolism and cancer. 
Table 1. BRD7's function. The role of BRD7 is summarized by cellular function.

\begin{tabular}{|c|c|c|}
\hline Function & Mechanism & Ref \\
\hline $\begin{array}{l}\text { Chromatin } \\
\text { Remodeling }\end{array}$ & $\begin{array}{l}\text { BRD7 binds to acetylated histone H3 through its bromodomain and BRD7 is involved in } \\
\text { chromatin remodeling. } \\
\text { The bromodomain of BRD7 contains the left-handed four-helix bundle topology, which } \\
\text { binds to acetylated lysine on histone H3 or H4. } \\
\text { BRD7 is a component of the PBAF chromatin remodeling complex. }\end{array}$ & $\begin{array}{l}\text { [17] } \\
{[16]}\end{array}$ \\
\hline $\begin{array}{c}\text { Transcriptional } \\
\text { Regulation }\end{array}$ & $\begin{array}{l}\text { BRD7 interacts with interferon regulatory factor } 2 \text { (IRF2). } \\
\text { Seh1 recruits Olig2 and BRD7 to form a complex and increases the transcription of } \\
\text { myelination-associated genes and chromatin modification. } \\
\text { BRD7 interacts with E1B-AP5, which is involved in mRNA processing and transport. The } \\
\text { complex associates with histones. } \\
\text { BRD7 binds to Smad proteins and increases TGF } \beta \text {-Smad-dependent transcriptional } \\
\text { activity. } \\
\text { BRD7 interacts with p53 and regulates the transcriptional activity of a subset of p53 target } \\
\text { genes involved in induction of replicative and oncogenic stress senescence. } \\
\text { BRD7 facilitates the recruitment of BRCA1 and Oct-1 to the ESR1 promoter and regulates } \\
\text { the transcription of ER } \alpha \text {. } \\
\text { The association between vitamin D receptor and PBAF is increased by BRD7 in } \beta \text { cells, } \\
\text { leading to transcriptional activation of genes involved in anti-inflammatory responses and } \\
\text { maintenance of } \beta \text { cell function. } \\
\text { BRD7 negatively regulates the transcriptional activity of androgen receptor in the } \\
\text { CWR22Rv1 prostate cancer cell line by binding to TRIM24, an activator of androgen } \\
\text { receptor. } \\
\text { BRD7 is required for the expression of the tumor suppressor XIAP-associating factor } 1 \text { in }\end{array}$ & $\begin{array}{l}\text { [18] } \\
{[19]}\end{array}$ \\
\hline $\begin{array}{l}\text { Cell Cycle } \\
\text { Progression }\end{array}$ & $\begin{array}{l}\text { Overexpression of BRD7 in HNE2 cells inhibits the G1-S phase transition and } \\
\text { downregulates expression of proteins in the ras/MEK/ER and E2F/Rb pathways. } \\
\text { BRD7 attenuates ras/raf/MEK/ERK signaling and represses cell proliferation. }\end{array}$ & $\begin{array}{l}\text { [27] } \\
\text { [28] }\end{array}$ \\
\hline Wnt Signaling & $\begin{array}{l}\text { BRD7 interacts with DVL1 and promotes Wnt signaling in HEK293T cells in a } \\
\text { DVL1-dependent manner by inhibiting the activity of GSK3 } \beta \text { and increasing the nuclear } \\
\text { translocation of } \beta \text {-catenin. } \\
\text { BRD7 overexpression in HNE1 nasopharyngeal carcinoma cells inhibits nuclear } \\
\text { accumulation of } \beta \text {-catenin. } \\
\text { BRD7 negatively regulates the } \beta \text {-catenin pathway in A2780 and SKOV3 ovarian cancer cell } \\
\text { lines by inhibiting nuclear translocation of } \beta \text {-catenin. } \\
\text { BRD7 expression is inhibited by microRNA-200c in HEC-1A and Ishikawa endometrial } \\
\text { carcinoma cells, which leads to increased nuclear translocation of } \beta \text {-catenin and } \\
\text { consequent increased transcription of cyclin D1 and c-myc. } \\
\text { BRD7 transcriptionally upregulates miR-3148 in C33A cells, which reduces Wnt3a } \\
\text { expression, and thus inhibits oncogenic Wnt3a/ } \beta \text {-catenin signaling. }\end{array}$ & [31] \\
\hline $\begin{array}{l}\text { Insulin } \\
\text { Signaling }\end{array}$ & $\begin{array}{l}\text { BRD7 interacts with p } 85 \alpha / \beta \text {, the regulatory subunits of PI3K, and increases their nuclear } \\
\text { translocation. This increases PI3K-Akt signaling in the liver, but attenuates Akt activity in } \\
\text { HeLa cervical cancer cells. } \\
\text { BRD7 increases phosphorylation of glycogen synthase kinase } 3 \beta \text { (GSK3 } \beta \text { ) at residue Ser9, } \\
\text { which leads to inactivation of GSK3 } \beta \text {. }\end{array}$ & {$[34,35]$} \\
\hline $\begin{array}{l}\text { Unfolded } \\
\text { Protein } \\
\text { Response }\end{array}$ & $\begin{array}{l}\text { BRD7 increases the nuclear translocation of the spliced form of X-box binding protein } 1 \\
\text { (XBP1s), upregulates the transcription of XBP1-target genes, and relieves ER stress. } \\
\text { BRD7 is required for hyperglycemia-induced apoptosis in H9c2 cardiomyoblasts. } \\
\text { Reduction of BRD7 in the heart of diabetic rats alleviates ER stress-induced myocardial } \\
\text { apoptosis. }\end{array}$ & [37] \\
\hline Inflammation & $\begin{array}{l}\text { MEFs that lack BRD7 and EII } \alpha \text {-Cre-derived BRD7-deficient mice show increased nuclear } \\
\text { translocation of p65 and NF- } \mathrm{kB} \text { transcriptional activity. } \\
\text { BRD7 knockdown in ApoE-knockout mice promotes atherosclerotic lesion formation and } \\
\text { vascular inflammation by promoting the transcriptional activity of NF- } \mathrm{kB} \text {. }\end{array}$ & [39] \\
\hline
\end{tabular}


Table 2. BRD7 and pathophysiology in various tissues. The role of BRD7 in diseases of various tissues is listed.

\begin{tabular}{|c|c|c|c|}
\hline Tissue Type & Disease & Mechanism of Progression & Ref. \\
\hline \multirow[t]{2}{*}{ Breast } & Cancer & $\begin{array}{l}\text { The BRD7 locus is frequently found deleted in human breast tumors. BRD7 is } \\
\text { required for p53-mediated transcription of a subset of p53 target genes. }\end{array}$ & [21] \\
\hline & Cancer & $\begin{array}{l}\text { BRD7 overexpression suppresses the epithelial-mesenchymal transition and } \\
\text { metastasis of breast cancer cells through increasing degradation of the } \\
\text { oncogenic protein YB1. }\end{array}$ & [40] \\
\hline Colon & Cancer & $\begin{array}{l}\text { BRD7 is downregulated in colorectal cancer tissues. BRD7 expression level is } \\
\text { correlated with survival time in colorectal cancer patients. }\end{array}$ & [41] \\
\hline \multirow{4}{*}{ Liver } & Obesity & $\begin{array}{l}\text { BRD7 levels are decreased in the liver of genetically obese } o b / o b \text { and high-fat } \\
\text { diet-induced obese mice. }\end{array}$ & [35] \\
\hline & Obesity & $\begin{array}{l}\text { Heterozygous whole-body and liver-specific knockout of BRD7 leads to } \\
\text { increased weight gain in mice, exacerbated by high-fat diet feeding. } \\
\text { Long-term upregulation of hepatic BRD7 reduces weight gain in mice } \\
\text { challenged with a high-fat diet. }\end{array}$ & [42] \\
\hline & $\begin{array}{c}\text { Type } 2 \\
\text { diabetes }\end{array}$ & $\begin{array}{l}\text { Upregulation of BRD7 in the liver of obese and type } 2 \text { diabetic mice decreases } \\
\text { blood glucose levels and improves glucose homeostasis. }\end{array}$ & {$[35,42]$} \\
\hline & Cancer & $\begin{array}{l}\text { BRD7 is downregulated in hepatocellular carcinoma (HCC), and higher } \\
\text { BRD7 levels are correlated with improved outcomes in HCC patients. } \\
\text { BRD7 inhibits HCC tumor growth in a xenograft mouse model. }\end{array}$ & [43] \\
\hline Lung & Cancer & $\begin{array}{l}\text { BRD7 expression levels are downregulated in non-small cell lung cancer } \\
\text { (NSCLC). Upregulated expression of microRNA-410 in NSCLC leads to } \\
\text { decreased BRD7 expression and increased Akt phosphorylation. }\end{array}$ & [44] \\
\hline \multirow{2}{*}{ Nasopharynx } & Cancer & BRD7 expression levels are downregulated in nasopharyngeal carcinoma. & [27] \\
\hline & Cancer & $\begin{array}{l}\text { High methylation frequency of the BRD7 promoter is found in tumor and } \\
\text { blood samples of patients with nasopharyngeal carcinoma. }\end{array}$ & [45] \\
\hline Bone & Cancer & $\begin{array}{l}\text { BRD7 is degraded by anaphase promoting complex in U2OS osteosarcoma } \\
\text { cells. Upregulation of degradation-resistant BRD7 reduces cell growth and } \\
\text { tumorigenesis. }\end{array}$ & [46] \\
\hline Ovary & Cancer & $\begin{array}{l}\text { The expression of BRD7 is decreased in high-grade serous ovarian cancer } \\
\text { tissues. Overexpression of BRD7 in A2780 and SKOV3 ovarian cancer cell } \\
\text { lines increases apoptosis and inhibits cell migration. }\end{array}$ & [31] \\
\hline Pancreas & Diabetes & $\begin{array}{l}\text { BRD7 increases the association between vitamin D receptor and PBAF in } \beta \\
\text { cells. This complex maintains } \beta \text { cell function and reduces glucose levels in } \\
d b / d b \text { and streptozotocin-treated mice. }\end{array}$ & [24] \\
\hline
\end{tabular}

\section{BRD7 in Metabolism}

BRD7 and insulin signaling. Insulin activates insulin receptor, which recruits and phosphorylates its substrate adaptor proteins, such as the insulin receptor substrate (IRS) family proteins. Activated IRS proteins are recognized by the regulatory subunits of phosphatidylinositol 3-kinase (PI3K), p85 $\alpha$ and $\mathrm{p} 85 \beta$. p 85 is required for the stability of the catalytic subunits of PI3K ( $\mathrm{p} 110 \alpha$ and p110 $\beta$ ) and mediates the recruitment of $\mathrm{p} 110$ subunits to upstream activators. PI3K leads to activation of effector proteins, such as Akt. However, when p 85 regulatory subunits are in excess of p110 catalytic subunits, p85s form homodimers that compete with p85-p110 heterodimers for binding to upstream activators of PI3K (e.g., IRS1) and impair insulin-induced PI3K signaling (Figure 1A) [47]. BRD7 regulates several major nodes in the insulin signaling pathway. BRD7 competes with p110 for binding to p85 [34]. BRD7 binds to the subset of $\mathrm{p} 85$ proteins that are not bound to $\mathrm{p} 110$, and transports these free $\mathrm{p} 85$ monomers to the nucleus, thereby increases insulin signaling (Figure 1A) [35]. However, in cells or tissues where the ratio of p85 to p110 is approximately 1:1, BRD7 upregulation decreases PI3K signaling by preventing $\mathrm{p} 85$ from binding to $\mathrm{p} 110$ (Figure 1B) [34]. Thus, the ratio of p85 to p110 serves a crucial role in cellular responses to insulin. Some tissues have approximately equal amounts of p85 and p110 proteins, while in other tissues (including the liver), p85 proteins are present in excess of p110 proteins. As a consequence, partial deletion of genes that encode various p85 isoforms improves 
insulin sensitivity $[48,49]$. Consistent with the biochemical model, knocking out both p $85 \alpha$ and p $85 \beta$ in the liver leads to insulin resistance [50].
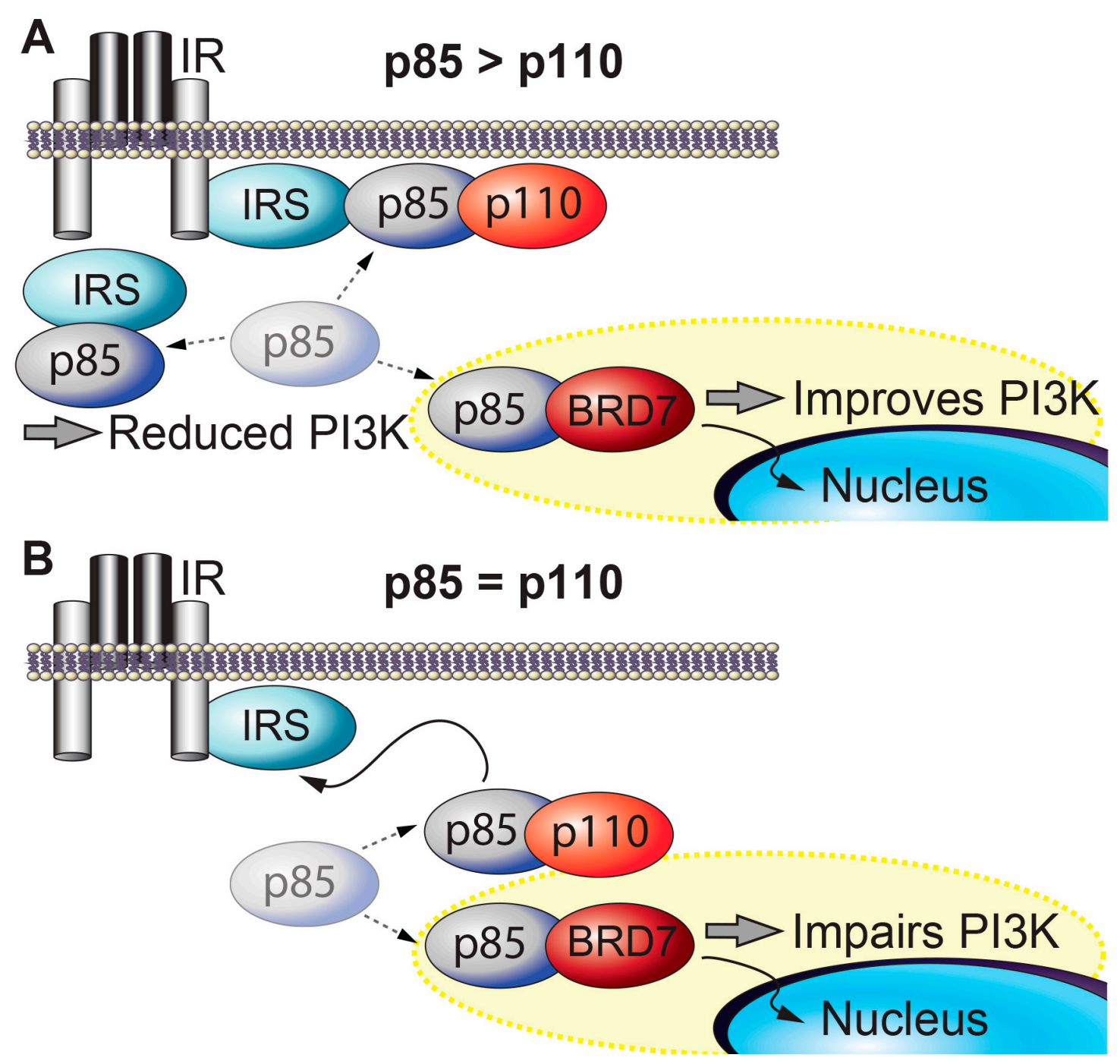

Figure 1. BRD7 and insulin signaling. (A) When $p 85$ is present in excess of $p 110$, free p85s inhibit PI3K (p85-p110) from binding to IRS. Overexpression of BRD7 removes free p85s from the cytoplasm to the nucleus and improves PI3K signaling. (B) When the amount of p85 and p110 is similar, BRD7 competes with p110 for binding to p85 and upregulation of BRD7 decreases PI3K signaling.

BRD7 increases phosphorylation of Akt at residues Thr308 and Ser473 and glycogen synthase kinase $3 \beta$ (GSK3 $\beta$ ) at residue Ser9, in the liver of mice as well as in mouse embryonic fibroblasts (MEFs) [36]. GSK3 $\beta$ is a target of Akt in the insulin signaling pathway and phosphorylation of GSK3 $\beta$ by Akt inactivates GSK3 $\beta$, activates glycogen synthase (GS), and increases glycogen synthesis. Thus, BRD7 likely responds to insulin by inhibiting GSK3 $\beta$ through Akt [36]. Notably, BRD7 increases the phosphorylation of GSK3 $\beta$ even in the absence of Akt1/2 [36]. BRD7 also increases phosphorylation of S6K in the absence of Akt1/2 activity as well [36]. In response to insulin, activation of S6K occurs at a later time, when Akt phosphorylation levels start to decrease [51]. Therefore, it is possible that BRD7 immediately responds to insulin and affects phosphorylation of GSK3 $\beta$ through Akt, but maintains its activity on GSK3 $\beta$ through S6K, at a later time point when the immediate effects of insulin have abated. Overall, this would not only enhance glycogen synthesis following insulin stimulation, but also after Akt becomes inactive while nutrients are still abundant and glucose is still being utilized. 
BRD7 in $\beta$ cell function. Insulin and amylin are synthesized in pancreatic $\beta$ cells and secreted in response to external stimuli. $\beta$ cells comprise more than half of the cells in the pancreas [52], but the mass and function of these cells are decreased in diabetes [53]. BRD7 is a component of the polybromo-associated BRG1-associated factor (PBAF) chromatin remodeling complex [16], while BRD9, another member of the BRD family proteins, associates with the mammalian SWI/SNF (BAF) complex [54]. The PBAF-BRD7 and BAF-BRD9 complexes participate in the maintenance and survival of pancreatic $\beta$ cells [24] through their interaction with the vitamin D receptor (VDR), which has been shown to contribute to the development of diabetes when defective [55]. BRD7 directs VDR to associate with PBAF, while BRD9 directs the association between VDR and BAF [24]. The VDR-PBAF-BRD7 linkage promotes a $\beta$ cell stress response, while VDR-BAF-BRD9 suppresses the function of the VDR [24]. Treatment of INS1 cells with a combination of calcipotriol (a synthetic VDR ligand) and i-BRD9 (an inhibitor of BRD9) increases the interaction between VDR and PBAF-BRD7 [24]; this, in turn, results in coordinated transcriptional responses that suppress inflammatory responses while promoting $\beta$ cell survival [24]. Treatment of $d b / d b$ and streptozotocin-treated C57BL/6J mice with calcipotriol and i-BRD9 improves glucose tolerance, reduces fasting blood glucose levels, and increases insulin secretion [24]. In summary, BRD7 in the PBAF complex is involved in a VDR-dependent transcriptional program that is critical for $\beta$ cell survival [24].

BRD7 and endoplasmic reticulum (ER) homeostasis. The ER is an organelle where secretory and membrane proteins are folded and modified into their functional structures. However, an accumulation of misfolded or unfolded proteins in the ER triggers a condition known as ER stress. Increased ER stress in turn activates a complex signaling cascade called the unfolded protein response (UPR) [56]. The three branches of the UPR consist of PKR-like ER kinase (PERK), activating transcription factor 6 (ATF6), and inositol-requiring enzyme 1 (IRE1). Activation of IRE1 by autophosphorylation enables the endoribonuclease activity of IRE1 and cleaves the mRNA of a transcription factor called X-box binding protein-1 (XBP1) $[57,58]$, leading to translation of a higher molecular weight protein, namely the spliced form of XBP1 (XBP1s) [59-62]. XBP1s is a master regulator of ER function and protein folding capacity [63-67], and a lack of one allele of XBP1 leads to the development of obesity and dysregulation of glucose homeostasis [56]. Increased ER stress and activation of the UPR are observed in obesity [56] and lead to the development of insulin resistance [56].

BRD7 interacts with p85 [34,35] through the iSH2 domain of p85 [34]; this interaction is required for p85-mediated nuclear translocation of XBP1s and for upregulation of XBP1s target genes that act to reduce ER stress (Figure 2) [35,68]. XBP1s is translocated to the nucleus in response to refeeding after a period of fasting, and relieves the ER stress caused by refeeding in the liver of lean wild-type mice [68]. In contrast, the nuclear translocation of XBP1s in response to refeeding is impaired in the liver of obese mice, and leads to increased ER stress [68]. Compared to lean mice, obese mice have significantly reduced hepatic BRD7 levels [35]. Use of an adenovirus-mediated transfer system to overexpress BRD7 in the liver of genetically obese $o b / o b$ and high-fat diet-induced obese mice induces the nuclear translocation of XBP1s, resulting in increased transcription of XBP1s target genes and a decrease in ER stress levels [35]. Upregulation of BRD7 in the liver of obese and type 2 diabetic mice reduces blood glucose levels and improves glucose homeostasis [35,42]. These findings suggest that BRD7 participates in UPR signaling and promotes euglycemia by restoring the activity of XBP1s [35,69].

BRD7 and obesity. Obesity is a major risk factor for many life-threatening complications, including diabetes [70], cardiovascular diseases [71,72], and cancer [73]. The worldwide prevalence of obesity has nearly tripled over the last 30 years [74]. Obesity leads to insulin resistance and is closely associated with type 2 diabetes; the global incidence of type 2 diabetes has paralleled that of obesity such that the number of adults with type 2 diabetes has quadrupled in the last four decades [75]. However, the mechanistic links between obesity, insulin resistance, and the development of type 2 diabetes remain elusive. 


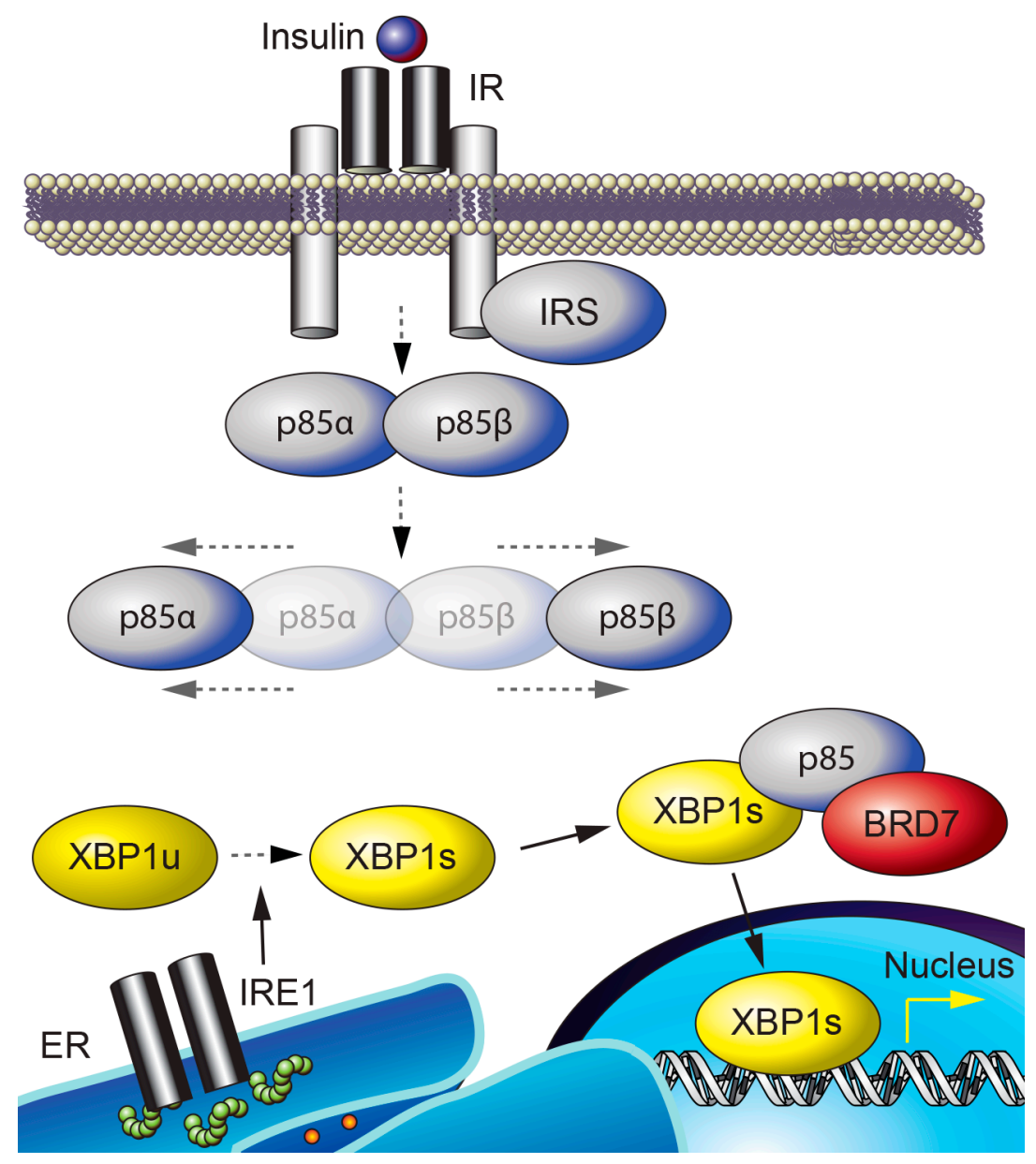

Figure 2. BRD7 and ER homeostasis. $p 85 \alpha$ and $p 85 \beta$ form a heterodimer that is dissociated by insulin stimulation. IRE1 is activated by autophosphorylation upon ER stress and cleaves the unspliced form of XBP1 (XBP1u), resulting in XBP1s. BRD7, p85, and XBP1s interact to form a complex that is required for the nuclear translocation of XBP1s.

Hepatic BRD7 levels are significantly reduced in genetically obese $o b / o b$ and high-fat diet-induced obese mice [35]. Upregulation of BRD7 in the liver protects against the development of obesity. BRD7 transgenic mice, in which hepatic BRD7 levels are elevated, do not gain as much body weight as wild-type control mice do when they are placed on a high-fat diet (45\% kcal from fat) [42]. BRD7 transgenic mice that are fed on a high-fat diet also display reduced plasma triglyceride levels [42] and decreased mRNA expression of Ppar $\gamma$, Fasn, Dgat2, and Srebf1 in white adipose tissue, showing that upregulation of BRD7 in the liver affects the expression of lipogenic genes in other organs [42]. These findings suggest that BRD7 is an important regulator of the development of obesity and lipid metabolism.

Conversely, mice with a mixed 129/SvJ and C57BL/6J background that lack one allele of BRD7 display increased body weight when placed on a high-fat diet [42] and exhibit high levels of hepatic triglyceride [42]. Liver-specific BRD7 knockout mice (on the same background) that are fed on a high-fat diet also display increased body weight and elevated hepatic triglyceride levels [42]. These studies indicate that a lack of hepatic BRD7 leads to the development of obesity. On the other hand, neither heterozygous whole-body BRD7 knockout mice nor liver-specific BRD7 knockout mice exhibit significant disruptions in glucose homeostasis, even when they are fed a high-fat diet [42]. This may be because of the difference in hepatic BRD7 levels between BRD7 knockouts and control mice that are fed on a high-fat diet is not enough to show strong phenotypic changes [13], given that 
the high-fat diet significantly reduces hepatic BRD7 levels [42]. However, knocking down BRD7 by BRD7-specific shRNA in mice after challenging them with a high-fat diet leads to hyperglycemia [13].

\section{BRD7 in Cancer}

BRD7 was first discovered as a gene that is downregulated in nasopharyngeal carcinoma (NPC) biopsies [12]. Since then, decreased expression of BRD7 has been reported in many other human cancers including breast cancer [21], ovarian cancer [31], osteosarcoma [46], pancreatic cancer [76], colorectal cancer [41], and lung adenocarcinoma [77]. A bioinformatic study also suggests that the BRD7 gene is frequently deleted in a large set of human cancers [22]. A number of mechanisms have been proposed by which BRD7 expression is downregulated in cancer (Tables 1 and 2): these include increased methylation of the BRD7 promoter [45,78], microRNA-mediated degradation of BRD7 mRNA [32,44,79], and increased ubiquitination of the BRD7 protein by E3 ligases [46,80]. Here, we summarize the role of BRD7 as a tumor suppressor in various organs.

BRD7 in NPC. Since the initial discovery that levels of BRD7 are decreased in NPC [27], BRD7's role as a tumor suppressor has been underscored in the HNE2 NPC cell line, in which BRD7 inhibits cell growth and G1-S cell cycle progression [27]. Upregulation of BRD7, in contrast, leads to differential expression of 12 genes that are involved in the MAPK/ERK and $\mathrm{Rb} / \mathrm{E} 2 \mathrm{~F}$ signaling cascades [27]: these include the downregulation of MEK1, GRB2, and E2F3, and upregulation of CDC42. This suggests that BRD7 is involved in cell proliferation [28] and that the suppression of cell cycle progression by BRD7 occurs via the transcriptional regulation of key proteins involved in the cell cycle. Further studies in HNE1 NPC cells as well as COS7 cells show that BRD7 is localized primarily in the nucleus, and contains a nuclear localization signal (NLS) from amino acid residues 65 to 96 [81]. Mutant BRD7 that lacks the NLS remains primarily in the cytoplasm, and has a diminished ability to regulate the G1 to $S$ progression as well as the expression of genes such as cyclin D1 and E2F3 [81].

Wnt $/ \beta$-catenin signaling plays important roles in cell growth, proliferation, and survival, and overactivation of Wnt/ $\beta$-catenin signaling is a common feature of cancer cells [82]. BRD7 inhibits the proliferation of HNE1 cells, by blocking the translocation of $\beta$-catenin to the nucleus. Negative regulation of $\beta$-catenin by overexpression of BRD7 downregulates the Wnt signaling pathway, as detected by decreased cyclin D1 and c-jun [30]. BRD7 also decreases phosphorylation of MEK and ERK, both of which are key proteins in the major pathways that promote cell cycle progression and cell proliferation [30]. On the other hand, BRD7 also reportedly enhances Wnt $/ \beta$-catenin signaling. In HEK293T cells, BRD7 interacts with disheveled 1 (Dvl-1), a member of the intracellular scaffolding protein family; this interaction dephosphorylates GSK3 $\beta$ at residue Tyr216, and thereby inhibits its kinase activity [29]. By negatively regulating GSK3 $\beta$, BRD7 enhances Wnt signaling, and also increases the nuclear translocation of $\beta$-catenin in COS-1 fibroblast-like cells [29]. How BRD7 differentially regulates $\beta$-catenin in different cell types and how this effect is related to its role as a tumor-suppressor remain to be resolved. Of note, overexpression of BRD7 negatively regulates $\beta$-catenin in cancer cells and positively regulates $\beta$-catenin in non-cancerous cells.

BRD7 in breast cancer. Although BRD7 was discovered in 1999, its role as a tumor suppressor was not well characterized until 2010, when several groups reported that BRD7 interacts with p53, a potent tumor suppressor that is frequently mutated in human cancers [83]. BRD7 binds to p53 through its $\mathrm{N}$-terminus, where the NLS is located [21]; this interaction is required for p53 to transcriptionally activate a subset of p53 target genes, such as P21, Hdm2, Ccng1, Rrm2b, Zmat3, and Fgf2 (Figure 3A) [21]. Yet other p53 target genes, such as Bax, Fas, Tnfrsf10a, Tnfrsf10b, and Dram1, do not require BRD7 as a co-transcriptional activator. Our understanding of how BRD7 selectively activates p53 is still incomplete. In the meantime, another group has reported that BRD7 is a p53-interacting partner, and also verified that only a subset of p53 target genes requires BRD7 as a co-activator of p53 [22]. Notably, depletion of BRD7 in BJ fibroblasts reduces expression of p21 (an inhibitor of cell cycle progression) in a p53-independent manner [22], and consequently delays proliferation and leads to premature senescence [84]. BRD7 also binds to p300, a histone-acetyl transferase that modifies histone 
tails, and the interaction between BRD7 and p53 is crucial for p300-dependent histone acetylation and also for p53 to upregulate gene transcription $[21,85]$.
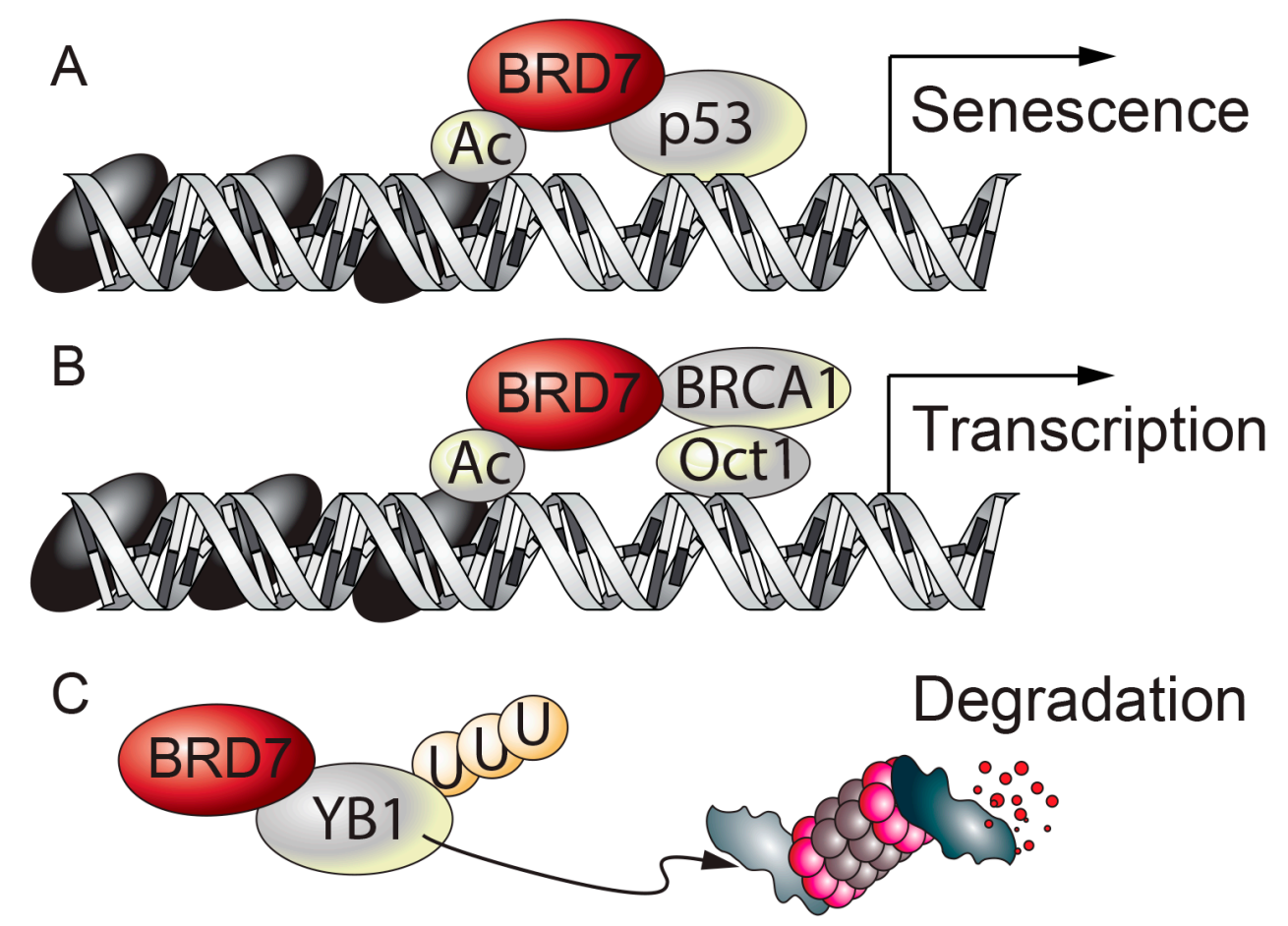

Figure 3. BRD7 and cancer. (A) BRD7 binds to p53 and increases the transcription of a subset of p53 target genes, leading to senescence. (B) BRD7 interacts with BRCA1 and recruits BRCA1 and Oct1 to the Esr1 promoter. (C) BRD7 binds to YB1 and leads to ubiquitin-mediated degradation of YB1. Ac: acetyl group. U: ubiquitin.

Around the same time as the above findings were published, BRD7 was identified as an interacting partner of BRCA1, another tumor suppressor associated with breast cancer, [23]; this interaction recruits BRCA1 and Oct1 to the Esr1 promoter, which encodes estrogen receptor $\alpha(E R \alpha)$ and in turn increases acetylation of histone H3 (Figure 3B) [23]. Loss of BRD7 or BRCA1 in breast cancer cells prevents expression of $\mathrm{ER} \alpha$, and makes the cells resistant to fulvestrant [23], an antiestrogen drug that is often used to treat breast cancer. Moreover, through its N-terminus, BRD7 binds to Y box binding protein-1 (YB1) [40], an oncogene that is upregulated in certain cancers [86]; this in turn leads to ubiquitin-mediated degradation of YB1 in the MDA231 and MCF7 breast cancer cell lines (Figure 3C) [40]. Epithelial-to-mesenchymal transition (EMT), wherein epithelial cells lose their adhesive characteristics and acquire mesenchymal stem cell-like features, is a cellular process that is often induced in carcinoma. BRD7 inhibits the EMT process, and maintains the cells' integrity in terms of the epithelial characteristics and low invasion ability [40].

BRD7 in female reproductive organs. Endometrial cancer, ovarian cancer, and cervical cancer are the most common reproductive cancers in women. Levels of BRD7 mRNA are decreased in serous ovarian cancer, especially in high-grade cancer [31]. Overexpression of BRD7 in A2780 and SKOV3 ovarian cancer cell lines reduces cell survival and increases apoptosis [31]. Furthermore, administration of BRD7 plasmids into mice that harbor an orthotopic A2780 cell line model of ovarian cancer leads to reduced tumor weight and decreased number of tumor nodules [31]. BRD7 negatively regulates $\beta$-catenin and thereby reduces MMP2 secretion in A2780 and SKOV3 cancerous cell lines [31]. Notably, BRD7's effects on cell viability, apoptosis, and cell invasion occur independent of the presence of p53 in A2780 and SKOV3 cells [31]. In addition, the role of microRNA (miRNA)-200 family is indicated in several carcinomas [87,88]; in particular, miR-200c is upregulated in endometrial carcinoma [32]. Microarray analysis and RT-PCR results from the HEC-1A uterus adenocarcinoma cell line show that 
miRNA-200c decreases the expression levels of BRD7 [32]. Overexpression of BRD7 in the HeLa cervical cancer cell line attenuates PI3K activity, as shown by decreased Akt phosphorylation at the Ser473 residue [34].

BRD7 in other organs. Prostate cancer is one of the top three leading causes of death from cancer for men in the United States. Expression of BRD7 is reduced in patients with prostate cancer [89]. BRD7 binds to tripartite motif-containing 24 (TRIM24) [25], a member of the transcriptional intermediary family 1 (TIF1), which associates with chromatin and regulates gene expression [90]. The interaction between BRD7 and TRIM24 in prostate cancer cells negatively regulates TRIM24 activity, and diminishes cell proliferation and cell growth [25].

Osteosarcoma is a type of bone cancer that develops from malignant neoplasm of cells of mesenchymal origin, such as osteoblasts. In human osteosarcoma tissues, the anaphase-promoting complex/cyclosome (APC/C), a complex of E3 ligases that mediates the ubiquitination of proteins during mitosis [91,92], targets BRD7 for ubiquitin-mediated degradation through its co-activators cdh1 and cdc20 [46]. Increased interaction between BRD7 and cdh1 or cdc20 leads to ubiquitin-mediated degradation of BRD7 in osteosarcoma [46]. Inhibiting APC/C activity, which participates in promoting osteosarcoma cell growth and tumor formation, decreases degradation of BRD7 and reduces the proliferation of cells in osteosarcoma [46].

Non-small cell lung carcinomas (NSCLC) account for more than $80 \%$ of all lung cancers, and includes adenocarcinoma, squamous cell carcinoma, and large cell carcinoma. BRD7 expression is decreased in NSCLC [77], and low levels of BRD7 are associated with reduced survival rates in lung adenocarcinoma patients [77]. Also, BRD7 is a target of miR-410, an oncogene that is upregulated in NSCLC [44]. BRD7 also transcriptionally upregulates a tumor suppressor called X-linked inhibitor of apoptosis associated factor 1 (XAF1) in human lung microvascular endothelial cells (HMVECs) [26]. XAF1 upregulation in HMVECs reduces cell proliferation, and induces cell cycle arrest [26]. In lung adenocarcinoma cells, XAF1 expression induces cell cycle arrest, cell senescence, and apoptosis [91,92]. Given that BRD7 is required for XAF1 transcription [26], BRD7 likely serves a tumor-suppressive role in NSCLC. BRD7 also induces ferroptosis in hepatic stellate cells [93], which raises the possibility that BRD7 also plays a role as a tumor suppressor by regulating cell death through iron-dependent accumulation of lipid hydroperoxides [94]. Furthermore, BRD7 is downregulated in hepatocellular carcinoma [43], while higher BRD7 expression levels are associated with improved survival of patients with hepatocellular carcinoma, pointing to a tumor-suppressive role of BRD7 in hepatocellular carcinoma.

\section{Discussion}

Many studies on the role of BRD7 consist of observation-based research rather than in-depth mechanistic studies. Nonetheless, they have shown that BRD7 is involved in a diverse range of biological disciplines. Over the last two decades, BRD7's diverse roles in multiple tissues and its involvement in a wide range of diseases have been highlighted, as delineated in this review. BRD7 was initially recognized as a tumor suppressor, but recent studies have provided evidence that BRD7 participates in the regulation of metabolism and insulin signaling pathway with detailed mechanistic underpinnings.

Type 2 diabetes is characterized by hyperglycemia, insulin resistance, and glucose intolerance [95]. Of the therapeutic agents used to reduce symptoms of type 2 diabetes, metformin is the first-line treatment and works by reducing hepatic glucose production [96]. Thiazolidinediones act by increasing insulin sensitivity, while sulfonylureas and meglitinides increase insulin secretion [97]. Other medications are known to inhibit specific proteins involved in glucose metabolism, such as DPP-4, GLP-1 receptor, and SGLT2 [97]. However, none of these drugs can cure type 2 diabetes, and one of the largest obstacles to developing a cure is our incomplete understanding of how insulin resistance and glucose intolerance develop. One of the proposed underlying causes for the development of obesity and type 2 diabetes is ER stress [98]. XBP1s plays a vital role in metabolic regulation [56,98,99] and XBP1 haplodeficiency leads to the development of obesity and type 2 diabetic features [56]. 
The mechanism by which XBP1s is translocated to the nucleus to serve as an active transcription factor was discovered in 2010, when the interaction between XBP1s and p85s, a component of the insulin signaling pathway, was unveiled $[68,100]$. Although the p85-p110 PI3K complex participates in the insulin signaling pathway in the cytosol, some reports showed the presence of p85 in the nucleus [34,35,101-103]. In 2014, the interaction between p85s and BRD7 was found to be critical for the nuclear translocation of p85 [34,35] as well as of XBP1s [35]. These results collectively support the role of BRD7 in the regulation of ER and glucose homeostases. The involvement of BRD7 in the regulation of glucose homeostasis was shown in two major metabolic tissues: the liver [35] and the pancreas [24].

Two studies reported that BRD7 affects the activity of Akt, downstream of PI3K signaling. Overexpression of BRD7 can increase [35] or decrease [34] the phosphorylation of Akt in response to insulin, depending on the amount of p85 present in relation to $\mathrm{p} 110$. When the ratio of $\mathrm{p} 85 / \mathrm{p} 110$ is high, excess p85 suppresses insulin signaling [47,104-107]. Under these conditions, reducing cytosolic p85 by BRD7-mediated nuclear translocation likely balances the ratio of p85 to p110, and enhances PI3K activity as well as Akt phosphorylation [35]. On the other hand, when p85 is not in excess of p110, PI3K is highly activated and leads to hyperactive Akt activity and increased cell proliferation [108]. Under these conditions, translocating p 85 into the nucleus by BRD7 reduces PI3K activity and decreases phosphorylation of Akt [34]. The dynamics of p85 are complex, and it seems that the response of p85 varies depending on the cell environment. For example, p85 not only binds to p110 to activate the PI3K pathway, but also associates with PTEN, which in turn dephosphorylates PIP 3 [109,110]. Likewise, upregulation of BRD7 improves insulin signaling in obesity, but inhibits PI3K activity in a cancerous state. Further studies are needed to unravel the complex roles of BRD7 and p85. However, given that the region of BRD7 that binds to p85 is highly conserved [34], it is likely that the role of BRD7 in PI3K signaling is related to more fundamental functions of $\mathrm{p} 85$ in the insulin signaling pathway.

Inhibition of GSK3 $\beta$ improves glucose tolerance in type 2 diabetic mice, while increased activation of GSK3 $\beta$ contributes to type 2 diabetes [111-113]. Therefore, GSK3 $\beta$ has been suggested as a therapeutic target for type 2 diabetes [113]. BRD7 enhances phosphorylation of GSK3 $\beta$ as well as $\mathrm{S6K}$, and 4E-BP1, downstream effector proteins of mTORC1 [36]. Of interest, BRD7 increases phosphorylation of GSK3 $\beta$ and S6K even in the absence of Akt activity, but 4E-BP1 phosphorylation is not affected by BRD7 overexpression without Akt [36]. These observations suggest that BRD7 not only responds to insulin stimulation (via Akt), but it can also sense nutrient abundance such that GSK3 $\beta$ is kept inactive when there is a sufficient energy source after meals (via S6K) without affecting the global translation of proteins through the activity of 4E-BP1. How BRD7 is able to respond to insulin and nutrient availability, and the precise pathway involved in such regulation have not been elucidated yet. Meanwhile, an abundance of amino acids is important for cell maintenance, cell survival, and biosynthesis. In particular, glutamine is used as a substrate for many biosynthetic pathways and glutamine metabolism has been discussed in cancer cells [114-116]. Considering the general role of BRD7 as a tumor suppressor, its regulation of the G1-S transition in NPC cells, and involvement in nutrient-sensing pathways, it is possible that BRD7 participates in the late G1 metabolic checkpoints mediated by essential amino acids, glutamine, and mTOR [117]. After unraveling the mechanism of action, the next step is to find compounds that upregulate BRD7 activity for the purpose of treating pathophysiological conditions.

The fact that mice with whole-body BRD7 knockout fail to survive embryonic development clearly points to a critical role for BRD7 in the normal functioning of cells and tissues [13]. In this mouse model, a cassette with $\beta$-galactosidase and the neomycin-resistance gene induces a frameshift and renders the BRD7 gene non-functional [13]. Of note, some studies used BRD7 whole-body knockout mice, which were generated with use of the Cre/LoxP recombination system, expressing Cre under the EII $\alpha$ promoter $[118,119]$. Cre/LoxP is a useful technology that has been widely used for tissue-specific genetic manipulation. However, under certain conditions, Cre mosaicism can lead to incomplete recombination in all cells, which then can exhibit inconsistent activity [120]. In particular, it was 
shown that commercially available EII $\alpha$-Cre mice can display mosaic recombination depending on whether the gene was inherited paternally or maternally [120]. Therefore, the possibility of having an incomplete recombination in the target tissues should be carefully evaluated. Regardless, the Cre/LoxP recombination system is generally accepted as a powerful tool for manipulating the genotypes of animals and has produced many significant discoveries. In light of this, we speculate that BRD7 knockout mice generated by the Cre/EII $\alpha$ promoter may survive even with a low expression level of BRD7 that is undetectable by standard methods for verifying genetic knockout. Nonetheless, they display strong phenotypes, such as male infertility [118] or impaired cognitive behavior [119].

\section{Conclusions}

Downregulation of BRD7 has been shown to be associated with many pathophysiological conditions, including obesity, diabetes, and cancer. Many reports also emphasize that upregulation of BRD7 alleviates or prevents the development of these pathological conditions. Additional investigations are needed to further uncover BRD7's mechanism of action. Nonetheless, the body of published data so far suggest that BRD7 can be an attractive therapeutic target for treating patients with type 2 diabetes and cancer.

Author Contributions: Conceptualization, S.W.P.; Literature research and compilation, S.W.P. and J.M.L.; Writing-Original Draft Preparation, S.W.P., Writing-Review \& Editing, S.W.P. and J.M.L.; Visualization, S.W.P.; Supervision, S.W.P.; Funding Acquisition, S.W.P. All authors have read and agreed to the published version of the manuscript.

Funding: This work was supported by the American Heart Association [grant number 18IPA34140057] and National Institutes of Health/NIDDK [grant number R01DK118244] provided to S.W.P.

Acknowledgments: We thank Lewis C. Cantley, Department of Medicine, Weill Cornell Medical College, for his helpful comments to the manuscript. We thank members of the Park laboratory for their contributions to editing the manuscript.

Conflicts of Interest: The authors declare no conflict of interest. 


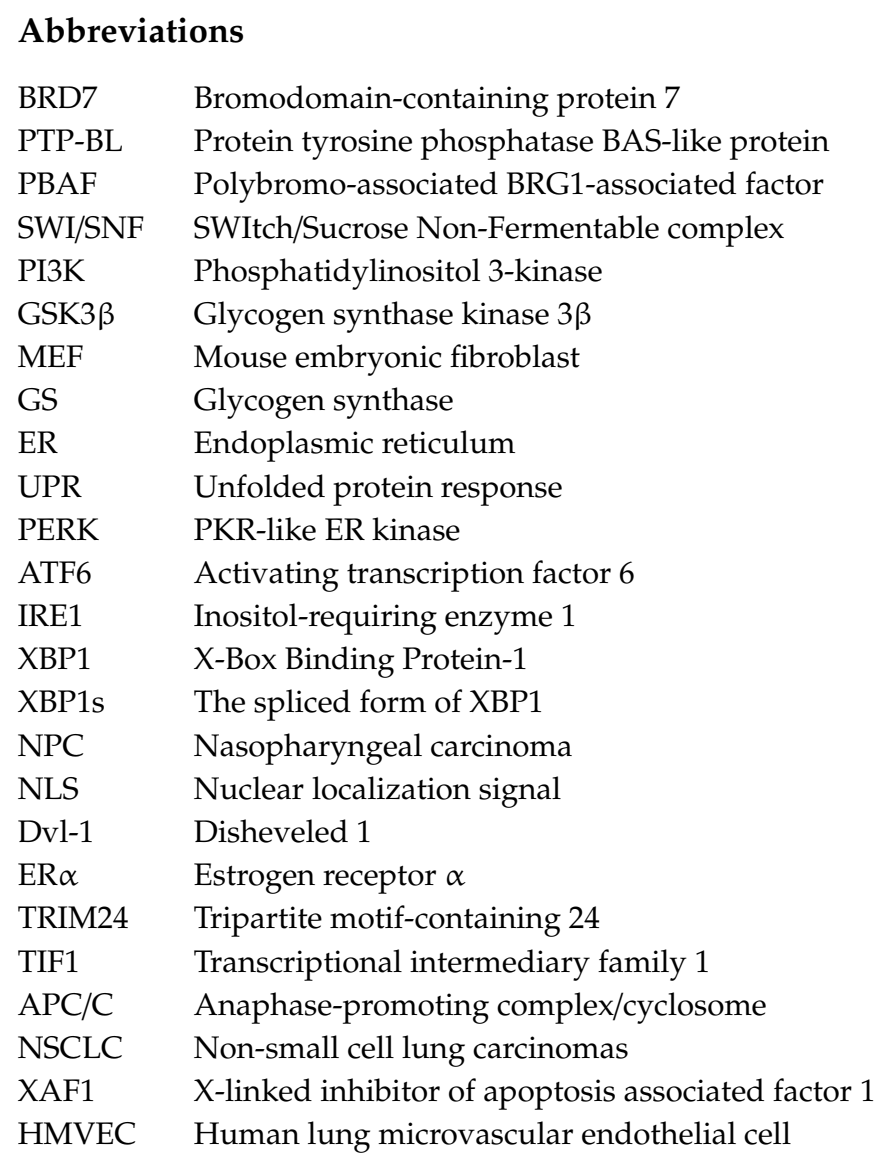

\section{References}

1. Haynes, S.R.; Dollard, C.; Winston, F.; Beck, S.; Trowsdale, J.; Dawid, I.B. The bromodomain: A conserved sequence found in human, Drosophila and yeast proteins. Nucleic Acids Res. 1992, 20, 2603. [CrossRef]

2. Jeanmougin, F.; Wurtz, J.M.; Le Douarin, B.; Chambon, P.; Losson, R. The bromodomain revisited. Trends Biochem. Sci 1997, 22, 151-153. [CrossRef]

3. Dhalluin, C.; Carlson, J.E.; Zeng, L.; He, C.; Aggarwal, A.K.; Zhou, M.M. Structure and ligand of a histone acetyltransferase bromodomain. Nature 1999, 399, 491-496. [CrossRef] [PubMed]

4. Winston, F.; Allis, C.D. The bromodomain: A chromatin-targeting module? Nat. Struct. Biol. 1999, 6, 601-604. [CrossRef]

5. Jacobson, R.H.; Ladurner, A.G.; King, D.S.; Tjian, R. Structure and function of a human TAFII250 double bromodomain module. Science 2000, 288, 1422-1425. [CrossRef]

6. Tamkun, J.W.; Deuring, R.; Scott, M.P.; Kissinger, M.; Pattatucci, A.M.; Kaufman, T.C.; Kennison, J.A. brahma: A regulator of Drosophila homeotic genes structurally related to the yeast transcriptional activator SNF2/SWI2. Cell 1992, 68, 561-572. [CrossRef]

7. Filippakopoulos, P.; Picaud, S.; Mangos, M.; Keates, T.; Lambert, J.P.; Barsyte-Lovejoy, D.; Felletar, I.; Volkmer, R.; Muller, S.; Pawson, T.; et al. Histone recognition and large-scale structural analysis of the human bromodomain family. Cell 2012, 149, 214-231. [CrossRef] [PubMed]

8. Kim, M.S.; Pinto, S.M.; Getnet, D.; Nirujogi, R.S.; Manda, S.S.; Chaerkady, R.; Madugundu, A.K.; Kelkar, D.S.; Isserlin, R.; Jain, S.; et al. A draft map of the human proteome. Nature 2014, 509, 575-581. [CrossRef]

9. Fujisawa, T.; Filippakopoulos, P. Functions of bromodomain-containing proteins and their roles in homeostasis and cancer. Nat. Rev. Mol. Cell Biol. 2017, 18, 246-262. [CrossRef]

10. Owen, D.J.; Ornaghi, P.; Yang, J.C.; Lowe, N.; Evans, P.R.; Ballario, P.; Neuhaus, D.; Filetici, P.; Travers, A.A. The structural basis for the recognition of acetylated histone $\mathrm{H} 4$ by the bromodomain of histone acetyltransferase gcn5p. EMBO J. 2000, 19, 6141-6149. [CrossRef] 
11. Sanchez, R.; Zhou, M.M. The role of human bromodomains in chromatin biology and gene transcription. Curr. Opin. Drug Discov. Devel. 2009, 12, 659-665.

12. Cuppen, E.; van Ham, M.; Pepers, B.; Wieringa, B.; Hendriks, W. Identification and molecular characterization of BP75, a novel bromodomain-containing protein. FEBS Lett. 1999, 459, 291-298. [CrossRef]

13. Kim, Y.; Andres Salazar Hernandez, M.; Herrema, H.; Delibasi, T.; Park, S.W. The role of BRD7 in embryo development and glucose metabolism. J. Cell Mol. Med. 2016, 20, 1561-1570. [CrossRef] [PubMed]

14. Peng, C.; Zhou, J.; Liu, H.Y.; Zhou, M.; Wang, L.L.; Zhang, Q.H.; Yang, Y.X.; Xiong, W.; Shen, S.R.; Li, X.L.; et al. The transcriptional regulation role of BRD7 by binding to acetylated histone through bromodomain. J. Cell Biochem. 2006, 97, 882-892. [CrossRef] [PubMed]

15. Kzhyshkowska, J.; Rusch, A.; Wolf, H.; Dobner, T. Regulation of transcription by the heterogeneous nuclear ribonucleoprotein E1B-AP5 is mediated by complex formation with the novel bromodomain-containing protein BRD7. Biochem. J. 2003, 371, 385-393. [CrossRef] [PubMed]

16. Kaeser, M.D.; Aslanian, A.; Dong, M.Q.; Yates, J.R., 3rd; Emerson, B.M. BRD7, a novel PBAF-specific SWI/SNF subunit, is required for target gene activation and repression in embryonic stem cells. J. Biol. Chem. 2008, 283, 32254-32263. [CrossRef]

17. Sun, H.; Liu, J.; Zhang, J.; Shen, W.; Huang, H.; Xu, C.; Dai, H.; Wu, J.; Shi, Y. Solution structure of BRD7 bromodomain and its interaction with acetylated peptides from histone $\mathrm{H} 3$ and H4. Biochem. Biophys. Res. Commun. 2007, 358, 435-441. [CrossRef]

18. Staal, A.; Enserink, J.M.; Stein, J.L.; Stein, G.S.; van Wijnen, A.J. Molecular characterization of celtix-1, a bromodomain protein interacting with the transcription factor interferon regulatory factor 2. J. Cell Physiol. 2000, 185, 269-279. [CrossRef]

19. Liu, Z.; Yan, M.; Liang, Y.; Liu, M.; Zhang, K.; Shao, D.; Jiang, R.; Li, L.; Wang, C.; Nussenzveig, D.R.; et al. Nucleoporin Seh1 Interacts with Olig2/Brd7 to Promote Oligodendrocyte Differentiation and Myelination. Neuron 2019, 102, 587-601.e587. [CrossRef]

20. Liu, T.; Zhao, M.; Liu, J.; He, Z.; Zhang, Y.; You, H.; Huang, J.; Lin, X.; Feng, X.H. Tumor suppressor bromodomain-containing protein 7 cooperates with Smads to promote transforming growth factor-beta responses. Oncogene 2017, 36, 362-372. [CrossRef]

21. Drost, J.; Mantovani, F.; Tocco, F.; Elkon, R.; Comel, A.; Holstege, H.; Kerkhoven, R.; Jonkers, J.; Voorhoeve, P.M.; Agami, R.; et al. BRD7 is a candidate tumour suppressor gene required for p53 function. Nat. Cell Biol. 2010, 12, 380-389. [CrossRef] [PubMed]

22. Burrows, A.E.; Smogorzewska, A.; Elledge, S.J. Polybromo-associated BRG1-associated factor components BRD7 and BAF180 are critical regulators of p53 required for induction of replicative senescence. Proc. Natl. Acad. Sci. USA 2010, 107, 14280-14285. [CrossRef] [PubMed]

23. Harte, M.T.; O’Brien, G.J.; Ryan, N.M.; Gorski, J.J.; Savage, K.I.; Crawford, N.T.; Mullan, P.B.; Harkin, D.P. BRD7, a subunit of SWI/SNF complexes, binds directly to BRCA1 and regulates BRCA1-dependent transcription. Cancer Res. 2010, 70, 2538-2547. [CrossRef] [PubMed]

24. Wei, Z.; Yoshihara, E.; He, N.; Hah, N.; Fan, W.; Pinto, A.F.M.; Huddy, T.; Wang, Y.; Ross, B.; Estepa, G.; et al. Vitamin D Switches BAF Complexes to Protect beta Cells. Cell 2018, 173, 1135-1149.e15. [CrossRef] [PubMed]

25. Kikuchi, M.; Okumura, F.; Tsukiyama, T.; Watanabe, M.; Miyajima, N.; Tanaka, J.; Imamura, M.; Hatakeyama, S. TRIM24 mediates ligand-dependent activation of androgen receptor and is repressed by a bromodomain-containing protein, BRD7, in prostate cancer cells. Biochim. Biophys. Acta 2009, 1793, 1828-1836. [CrossRef]

26. Heo, J.I.; Kim, W.; Choi, K.J.; Bae, S.; Jeong, J.H.; Kim, K.S. XIAP-associating factor 1, a transcriptional target of BRD7, contributes to endothelial cell senescence. Oncotarget 2016, 7, 5118-5130. [CrossRef]

27. Zhou, J.; Ma, J.; Zhang, B.C.; Li, X.L.; Shen, S.R.; Zhu, S.G.; Xiong, W.; Liu, H.Y.; Huang, H.; Zhou, M.; et al. BRD7, a novel bromodomain gene, inhibits G1-S progression by transcriptionally regulating some important molecules involved in ras/MEK/ERK and Rb/E2F pathways. J. Cell Physiol. 2004, 200, 89-98. [CrossRef]

28. Zhang, Q.; Wei, L.; Yang, H.; Yang, W.; Yang, Q.; Zhang, Z.; Wu, K.; Wu, J. Bromodomain containing protein represses the Ras/Raf/MEK/ERK pathway to attenuate human hepatoma cell proliferation during HCV infection. Cancer Lett. 2016, 371, 107-116. [CrossRef]

29. Kim, S.; Lee, J.; Park, J.; Chung, J. BP75, bromodomain-containing M(r) 75,000 protein, binds dishevelled-1 and enhances Wnt signaling by inactivating glycogen synthase kinase-3 beta. Cancer Res. 2003, 63, 4792-4795. 
30. Peng, C.; Liu, H.Y.; Zhou, M.; Zhang, L.M.; Li, X.L.; Shen, S.R.; Li, G.Y. BRD7 suppresses the growth of Nasopharyngeal Carcinoma cells (HNE1) through negatively regulating beta-catenin and ERK pathways. Mol. Cell Biochem. 2007, 303, 141-149. [CrossRef]

31. Park, Y.A.; Lee, J.W.; Kim, H.S.; Lee, Y.Y.; Kim, T.J.; Choi, C.H.; Choi, J.J.; Jeon, H.K.; Cho, Y.J.; Ryu, J.Y.; et al. Tumor suppressive effects of bromodomain-containing protein 7 (BRD7) in epithelial ovarian carcinoma. Clin. Cancer Res. 2014, 20, 565-575. [CrossRef] [PubMed]

32. Park, Y.A.; Lee, J.W.; Choi, J.J.; Jeon, H.K.; Cho, Y.; Choi, C.; Kim, T.J.; Lee, N.W.; Kim, B.G.; Bae, D.S. The interactions between MicroRNA-200c and BRD7 in endometrial carcinoma. Gynecol. Oncol. 2012, 124, 125-133. [CrossRef] [PubMed]

33. Wang, H.; Xie, Y. BRD7-Mediated miR-3148 Inhibits Progression of Cervical Cancer by Targeting Wnt3a/beta-Catenin Pathway. Reprod. Sci. 2020, 27, 877-887. [CrossRef] [PubMed]

34. Chiu, Y.H.; Lee, J.Y.; Cantley, L.C. BRD7, a tumor suppressor, interacts with p85alpha and regulates PI3K activity. Mol. Cell 2014, 54, 193-202. [CrossRef] [PubMed]

35. Park, S.W.; Herrema, H.; Salazar, M.; Cakir, I.; Cabi, S.; Basibuyuk Sahin, F.; Chiu, Y.H.; Cantley, L.C.; Ozcan, U. BRD7 regulates XBP1s' activity and glucose homeostasis through its interaction with the regulatory subunits of PI3K. Cell Metab. 2014, 20, 73-84. [CrossRef] [PubMed]

36. Golick, L.; Han, Y.; Kim, Y.; Park, S.W. BRD7 regulates the insulin-signaling pathway by increasing phosphorylation of GSK3beta. Cell Mol. Life Sci. 2018, 75, 1857-1869. [CrossRef] [PubMed]

37. Wang, X.M.; Wang, Y.C.; Liu, X.J.; Wang, Q.; Zhang, C.M.; Zhang, L.P.; Liu, H.; Zhang, X.Y.; Mao, Y.; Ge, Z.M. BRD7 mediates hyperglycaemia-induced myocardial apoptosis via endoplasmic reticulum stress signalling pathway. J. Cell Mol. Med. 2017, 21, 1094-1105. [CrossRef]

38. Zhao, R.; Liu, Y.; Wang, H.; Yang, J.; Niu, W.; Fan, S.; Xiong, W.; Ma, J.; Li, X.; Phillips, J.B.; et al. BRD7 plays an anti-inflammatory role during early acute inflammation by inhibiting activation of the NF-small ka, CyrillicB signaling pathway. Cell Mol. Immunol. 2017, 14, 830-841. [CrossRef]

39. Yan, A.; Yue, T.; Li, L.; Li, W.; Li, Q.; Li, J. Bromodomain-containing protein 7 deficiency augments atherosclerotic lesions in ApoE(-/-) mice. Biochem. Biophys. Res. Commun. 2018, 495, 2202-2208. [CrossRef]

40. Niu, W.; Luo, Y.; Zhou, Y.; Li, M.; Wu, C.; Duan, Y.; Wang, H.; Fan, S.; Li, Z.; Xiong, W.; et al. BRD7 suppresses invasion and metastasis in breast cancer by negatively regulating YB1-induced epithelial-mesenchymal transition. J. Exp. Clin. Cancer Res. 2020, 39, 30. [CrossRef]

41. Wu, W.J.; Hu, K.S.; Chen, D.L.; Zeng, Z.L.; Luo, H.Y.; Wang, F.; Wang, D.S.; Wang, Z.Q.; He, F.; Xu, R.H. Prognostic relevance of BRD7 expression in colorectal carcinoma. Eur. J. Clin. Investig. 2013, 43, 131-140. [CrossRef] [PubMed]

42. Lee, J.M.; Kim, Y.; Salazar Hernandez, M.A.; Han, Y.; Liu, R.; Park, S.W. BRD7 deficiency leads to the development of obesity and hyperglycemia. Sci. Rep. 2019, 9, 5327. [CrossRef] [PubMed]

43. Chen, C.L.; Wang, Y.; Pan, Q.Z.; Tang, Y.; Wang, Q.J.; Pan, K.; Huang, L.X.; He, J.; Zhao, J.J.; Jiang, S.S.; et al. Bromodomain-containing protein 7 (BRD7) as a potential tumor suppressor in hepatocellular carcinoma. Oncotarget 2016, 7, 16248-16261. [CrossRef] [PubMed]

44. Li, D.; Yang, Y.; Zhu, G.; Liu, X.; Zhao, M.; Li, X.; Yang, Q. MicroRNA-410 promotes cell proliferation by targeting BRD7 in non-small cell lung cancer. FEBS Lett. 2015, 589, 2218-2223. [CrossRef] [PubMed]

45. Liu, H.; Zhang, L.; Niu, Z.; Zhou, M.; Peng, C.; Li, X.; Deng, T.; Shi, L.; Tan, Y.; Li, G. Promoter methylation inhibits BRD7 expression in human nasopharyngeal carcinoma cells. BMC Cancer 2008, 8, 253. [CrossRef] [PubMed]

46. Hu, K.; Liao, D.; Wu, W.; Han, A.J.; Shi, H.J.; Wang, F.; Wang, X.; Zhong, L.; Duan, T.; Wu, Y.; et al. Targeting the anaphase-promoting complex/cyclosome (APC/C)- bromodomain containing 7 (BRD7) pathway for human osteosarcoma. Oncotarget 2014, 5, 3088-3100. [CrossRef]

47. Luo, J.; Field, S.J.; Lee, J.Y.; Engelman, J.A.; Cantley, L.C. The p85 regulatory subunit of phosphoinositide 3-kinase down-regulates IRS-1 signaling via the formation of a sequestration complex. J. Cell Biol. 2005, 170, 455-464. [CrossRef]

48. Ueki, K.; Yballe, C.M.; Brachmann, S.M.; Vicent, D.; Watt, J.M.; Kahn, C.R.; Cantley, L.C. Increased insulin sensitivity in mice lacking p85beta subunit of phosphoinositide 3-kinase. Proc. Natl. Acad. Sci. USA 2002, 99, 419-424. [CrossRef] 
49. Mauvais-Jarvis, F.; Ueki, K.; Fruman, D.A.; Hirshman, M.F.; Sakamoto, K.; Goodyear, L.J.; Iannacone, M.; Accili, D.; Cantley, L.C.; Kahn, C.R. Reduced expression of the murine p85alpha subunit of phosphoinositide 3-kinase improves insulin signaling and ameliorates diabetes. J. Clin. Investig. 2002, 109, 141-149. [CrossRef]

50. Taniguchi, C.M.; Kondo, T.; Sajan, M.; Luo, J.; Bronson, R.; Asano, T.; Farese, R.; Cantley, L.C.; Kahn, C.R. Divergent regulation of hepatic glucose and lipid metabolism by phosphoinositide 3-kinase via Akt and PKClambda/zeta. Cell Metab. 2006, 3, 343-353. [CrossRef]

51. Dalle Pezze, P.; Sonntag, A.G.; Thien, A.; Prentzell, M.T.; Godel, M.; Fischer, S.; Neumann-Haefelin, E.; Huber, T.B.; Baumeister, R.; Shanley, D.P.; et al. A dynamic network model of mTOR signaling reveals TSC-independent mTORC2 regulation. Sci. Signal. 2012, 5, ra25. [CrossRef] [PubMed]

52. Dolensek, J.; Rupnik, M.S.; Stozer, A. Structural similarities and differences between the human and the mouse pancreas. Islets 2015, 7, e1024405. [CrossRef]

53. Stoffers, D.A. The development of beta-cell mass: Recent progress and potential role of GLP-1. Horm. Metab. Res. 2004, 36, 811-821. [CrossRef] [PubMed]

54. Wang, X.; Wang, S.; Troisi, E.C.; Howard, T.P.; Haswell, J.R.; Wolf, B.K.; Hawk, W.H.; Ramos, P.; Oberlick, E.M.; Tzvetkov, E.P.; et al. BRD9 defines a SWI/SNF sub-complex and constitutes a specific vulnerability in malignant rhabdoid tumors. Nat. Commun. 2019, 10, 1881. [CrossRef] [PubMed]

55. Takiishi, T.; Gysemans, C.; Bouillon, R.; Mathieu, C. Vitamin D and diabetes. Endocrinol. Metab. Clin. 2010, $39,419-446$, table of contents. [CrossRef]

56. Ozcan, U.; Cao, Q.; Yilmaz, E.; Lee, A.H.; Iwakoshi, N.N.; Ozdelen, E.; Tuncman, G.; Gorgun, C.; Glimcher, L.H.; Hotamisligil, G.S. Endoplasmic reticulum stress links obesity, insulin action, and type 2 diabetes. Science 2004, 306, 457-461. [CrossRef]

57. Cox, J.S.; Shamu, C.E.; Walter, P. Transcriptional induction of genes encoding endoplasmic reticulum resident proteins requires a transmembrane protein kinase. Cell 1993, 73, 1197-1206. [CrossRef]

58. Mori, K.; Ma, W.; Gething, M.J.; Sambrook, J. A transmembrane protein with a cdc2+/CDC28-related kinase activity is required for signaling from the ER to the nucleus. Cell 1993, 74, 743-756.

59. Calfon, M.; Zeng, H.; Urano, F.; Till, J.H.; Hubbard, S.R.; Harding, H.P.; Clark, S.G.; Ron, D. IRE1 couples endoplasmic reticulum load to secretory capacity by processing the XBP-1 mRNA. Nature 2002, 415, 92-96. [CrossRef]

60. Dan, H.C.; Sun, M.; Yang, L.; Feldman, R.I.; Sui, X.M.; Ou, C.C.; Nellist, M.; Yeung, R.S.; Halley, D.J.; Nicosia, S.V.; et al. Phosphatidylinositol 3-kinase/Akt pathway regulates tuberous sclerosis tumor suppressor complex by phosphorylation of tuberin. J. Biol. Chem. 2002, 277, 35364-35370. [CrossRef]

61. Yoshida, H.; Matsui, T.; Yamamoto, A.; Okada, T.; Mori, K. XBP1 mRNA is induced by ATF6 and spliced by IRE1 in response to ER stress to produce a highly active transcription factor. Cell 2001, 107, 881-891. [CrossRef]

62. Lee, K.; Tirasophon, W.; Shen, X.; Michalak, M.; Prywes, R.; Okada, T.; Yoshida, H.; Mori, K.; Kaufman, R.J. IRE1-mediated unconventional mRNA splicing and S2P-mediated ATF6 cleavage merge to regulate XBP1 in signaling the unfolded protein response. Genes Dev. 2002, 16, 452-466. [CrossRef] [PubMed]

63. Lee, A.H.; Iwakoshi, N.N.; Glimcher, L.H. XBP-1 regulates a subset of endoplasmic reticulum resident chaperone genes in the unfolded protein response. Mol. Cell Biol. 2003, 23, 7448-7459. [CrossRef]

64. Sriburi, R.; Jackowski, S.; Mori, K.; Brewer, J.W. XBP1: A link between the unfolded protein response, lipid biosynthesis, and biogenesis of the endoplasmic reticulum. J. Cell Biol. 2004, 167, 35-41. [CrossRef] [PubMed]

65. Sriburi, R.; Bommiasamy, H.; Buldak, G.L.; Robbins, G.R.; Frank, M.; Jackowski, S.; Brewer, J.W. Coordinate regulation of phospholipid biosynthesis and secretory pathway gene expression in XBP-1(S)-induced endoplasmic reticulum biogenesis. J. Biol. Chem. 2007, 282, 7024-7034. [CrossRef]

66. Ron, D.; Walter, P. Signal integration in the endoplasmic reticulum unfolded protein response. Nat. Rev. Mol. Cell Biol. 2007, 8, 519-529. [CrossRef] [PubMed]

67. Zhang, K.; Kaufman, R.J. From endoplasmic-reticulum stress to the inflammatory response. Nature 2008, 454, 455-462. [CrossRef] [PubMed]

68. Park, S.W.; Zhou, Y.; Lee, J.; Lu, A.; Sun, C.; Chung, J.; Ueki, K.; Ozcan, U. The regulatory subunits of PI3K, p85alpha and p85beta, interact with XBP-1 and increase its nuclear translocation. Nat. Med. 2010, 16, 429-437. [CrossRef] 
69. Zhou, Y.; Lee, J.; Reno, C.M.; Sun, C.; Park, S.W.; Chung, J.; Lee, J.; Fisher, S.J.; White, M.F.; Biddinger, S.B.; et al. Regulation of glucose homeostasis through a XBP-1-FoxO1 interaction. Nat. Med. 2011, 17, 356-365. [CrossRef]

70. Mokdad, A.H.; Ford, E.S.; Bowman, B.A.; Dietz, W.H.; Vinicor, F.; Bales, V.S.; Marks, J.S. Prevalence of obesity, diabetes, and obesity-related health risk factors, 2001. JAMA 2003, 289, 76-79. [CrossRef]

71. Van Gaal, L.F.; Mertens, I.L.; De Block, C.E. Mechanisms linking obesity with cardiovascular disease. Nature 2006, 444, 875-880. [CrossRef] [PubMed]

72. Ortega, F.B.; Lavie, C.J.; Blair, S.N. Obesity and Cardiovascular Disease. Circ. Res. 2016, 118, $1752-1770$. [CrossRef] [PubMed]

73. Pischon, T.; Nothlings, U.; Boeing, H. Obesity and cancer. Proc. Nutr. Soc. 2008, 67, 128-145. [CrossRef]

74. GBD 2015 Obesity Collaborators; Afshin, A.; Forouzanfar, M.H.; Reitsma, M.B.; Sur, P.; Estep, K.; Lee, A.; Marczak, L.; Mokdad, A.H.; Moradi-Lakeh, M.; et al. Health Effects of Overweight and Obesity in 195 Countries over 25 Years. N. Engl. J. Med. 2017, 377, 13-27. [CrossRef]

75. NCD Risk Factor Collaboration. Worldwide trends in diabetes since 1980: A pooled analysis of 751 population-based studies with 4.4 million participants. Lancet 2016, 387, 1513-1530. [CrossRef]

76. Zhu, B.; Tian, J.; Zhong, R.; Tian, Y.; Chen, W.; Qian, J.; Zou, L.; Xiao, M.; Shen, N.; Yang, H.; et al. Genetic variants in the SWI/SNF complex and smoking collaborate to modify the risk of pancreatic cancer in a Chinese population. Mol. Carcinog. 2015, 54, 761-768. [CrossRef] [PubMed]

77. Gao, Y.; Wang, B.; Gao, S. BRD7 Acts as a Tumor Suppressor Gene in Lung Adenocarcinoma. PLoS ONE 2016, 11, e0156701. [CrossRef]

78. Balasubramanian, A.; Subramaniam, R.; Narayanan, V.; Annamalai, T.; Ramanathan, A. BRD7 promoter hypermethylation as an indicator of well differentiated oral squamous cell carcinomas. Asian Pac. J. Cancer Prev. 2015, 16, 1615-1619. [CrossRef]

79. Xue, Z.; Zhao, J.; Niu, L.; An, G.; Guo, Y.; Ni, L. Up-Regulation of MiR-300 Promotes Proliferation and Invasion of Osteosarcoma by Targeting BRD7. PLoS ONE 2015, 10, e0127682. [CrossRef]

80. Hu, K.; Wu, W.; Li, Y.; Lin, L.; Chen, D.; Yan, H.; Xiao, X.; Chen, H.; Chen, Z.; Zhang, Y.; et al. Poly(ADP-ribosyl)ation of BRD7 by PARP1 confers resistance to DNA-damaging chemotherapeutic agents. EMBO Rep. 2019, 20, e46166. [CrossRef]

81. Zhou, M.; Liu, H.; Xu, X.; Zhou, H.; Li, X.; Peng, C.; Shen, S.; Xiong, W.; Ma, J.; Zeng, Z.; et al. Identification of nuclear localization signal that governs nuclear import of BRD7 and its essential roles in inhibiting cell cycle progression. J. Cell Biochem. 2006, 98, 920-930. [CrossRef] [PubMed]

82. MacDonald, B.T.; Tamai, K.; He, X. Wnt/beta-catenin signaling: Components, mechanisms, and diseases. Dev. Cell 2009, 17, 9-26. [CrossRef] [PubMed]

83. Olivier, M.; Hollstein, M.; Hainaut, P. TP53 mutations in human cancers: Origins, consequences, and clinical use. Cold Spring Harb. Perspect. Biol. 2010, 2, a001008. [CrossRef] [PubMed]

84. El-Deiry, W.S. p21(WAF1) Mediates Cell-Cycle Inhibition, Relevant to Cancer Suppression and Therapy. Cancer Res. 2016, 76, 5189-5191. [CrossRef]

85. Mantovani, F.; Drost, J.; Voorhoeve, P.M.; Del Sal, G.; Agami, R. Gene regulation and tumor suppression by the bromodomain-containing protein BRD7. Cell Cycle 2010, 9, 2777-2781. [CrossRef]

86. Kohno, K.; Izumi, H.; Uchiumi, T.; Ashizuka, M.; Kuwano, M. The pleiotropic functions of the Y-box-binding protein, YB-1. Bioessays 2003, 25, 691-698. [CrossRef]

87. Gregory, P.A.; Bert, A.G.; Paterson, E.L.; Barry, S.C.; Tsykin, A.; Farshid, G.; Vadas, M.A.; Khew-Goodall, Y.; Goodall, G.J. The miR-200 family and miR-205 regulate epithelial to mesenchymal transition by targeting ZEB1 and SIP1. Nat. Cell Biol. 2008, 10, 593-601. [CrossRef]

88. Gregory, P.A.; Bracken, C.P.; Bert, A.G.; Goodall, G.J. MicroRNAs as regulators of epithelial-mesenchymal transition. Cell Cycle 2008, 7, 3112-3118. [CrossRef]

89. Liang, Y.; Dong, B.; Shen, J.; Ma, C.; Ma, Z. Clinical significance of bromodomain-containing protein 7 and its association with tumor progression in prostate cancer. Oncol. Lett. 2019, 17, 849-856. [CrossRef]

90. Torres-Padilla, M.E.; Zernicka-Goetz, M. Role of TIF1alpha as a modulator of embryonic transcription in the mouse zygote. J. Cell Biol. 2006, 174, 329-338. [CrossRef]

91. Peters, J.M. The anaphase promoting complex/cyclosome: A machine designed to destroy. Nat. Rev. Mol. Cell Biol. 2006, 7, 644-656. [CrossRef] [PubMed]

92. Pines, J. The APC/C: A smorgasbord for proteolysis. Mol. Cell 2009, 34, 135-136. [CrossRef] [PubMed] 
93. Zhang, Z.; Guo, M.; Shen, M.; Kong, D.; Zhang, F.; Shao, J.; Tan, S.; Wang, S.; Chen, A.; Cao, P.; et al. The BRD7-P53-SLC25A28 axis regulates ferroptosis in hepatic stellate cells. Redox Biol. 2020, 36, 101619. [CrossRef] [PubMed]

94. Stockwell, B.R.; Friedmann Angeli, J.P.; Bayir, H.; Bush, A.I.; Conrad, M.; Dixon, S.J.; Fulda, S.; Gascon, S.; Hatzios, S.K.; Kagan, V.E.; et al. Ferroptosis: A Regulated Cell Death Nexus Linking Metabolism, Redox Biology, and Disease. Cell 2017, 171, 273-285. [CrossRef]

95. Edelman, S.V. Type II diabetes mellitus. Adv. Intern. Med. 1998, 43, 449-500.

96. Madiraju, A.K.; Erion, D.M.; Rahimi, Y.; Zhang, X.M.; Braddock, D.T.; Albright, R.A.; Prigaro, B.J.; Wood, J.L.; Bhanot, S.; MacDonald, M.J.; et al. Metformin suppresses gluconeogenesis by inhibiting mitochondrial glycerophosphate dehydrogenase. Nature 2014, 510, 542-546. [CrossRef]

97. Chowdhury, T.A.; Grant, P. Drug therapies in type 2 diabetes: An era of personalised medicine. Clin. Med. 2016, 16, 441-447. [CrossRef]

98. Park, S.W.; Ozcan, U. Potential for therapeutic manipulation of the UPR in disease. Semin. Immunopathol. 2013, 35, 351-373. [CrossRef]

99. Park, S.W.; Zhou, Y.; Lee, J.; Ozcan, U. Sarco(endo)plasmic reticulum $\mathrm{Ca}^{2+}$-ATPase $2 \mathrm{~b}$ is a major regulator of endoplasmic reticulum stress and glucose homeostasis in obesity. Proc. Natl. Acad. Sci. USA 2010, 107, 19320-19325. [CrossRef]

100. Winnay, J.N.; Boucher, J.; Mori, M.A.; Ueki, K.; Kahn, C.R. A regulatory subunit of phosphoinositide 3-kinase increases the nuclear accumulation of X-box-binding protein-1 to modulate the unfolded protein response. Nat. Med. 2010, 16, 438-445. [CrossRef]

101. Bavelloni, A.; Santi, S.; Sirri, A.; Riccio, M.; Faenza, I.; Zini, N.; Cecchi, S.; Ferri, A.; Auron, P.; Maraldi, N.M.; et al. Phosphatidylinositol 3-kinase translocation to the nucleus is induced by interleukin 1 and prevented by mutation of interleukin 1 receptor in human osteosarcoma Saos-2 cells. J. Cell Sci. 1999, 112 Pt 5, 631-640.

102. Martelli, A.M.; Borgatti, P.; Bortul, R.; Manfredini, M.; Massari, L.; Capitani, S.; Neri, L.M. Phosphatidylinositol 3-kinase translocates to the nucleus of osteoblast-like MC3T3-E1 cells in response to insulin-like growth factor I and platelet-derived growth factor but not to the proapoptotic cytokine tumor necrosis factor alpha. J. Bone Miner. Res. 2000, 15, 1716-1730. [CrossRef] [PubMed]

103. Neri, L.M.; Milani, D.; Bertolaso, L.; Stroscio, M.; Bertagnolo, V.; Capitani, S. Nuclear translocation of phosphatidylinositol 3-kinase in rat pheochromocytoma PC 12 cells after treatment with nerve growth factor. Cell Mol. Biol. (Noisy-le-grand) 1994, 40, 619-626.

104. Taniguchi, C.M.; Aleman, J.O.; Ueki, K.; Luo, J.; Asano, T.; Kaneto, H.; Stephanopoulos, G.; Cantley, L.C.; Kahn, C.R. The p85alpha regulatory subunit of phosphoinositide 3-kinase potentiates c-Jun N-terminal kinase-mediated insulin resistance. Mol. Cell Biol. 2007, 27, 2830-2840. [CrossRef] [PubMed]

105. Taniguchi, C.M.; Tran, T.T.; Kondo, T.; Luo, J.; Ueki, K.; Cantley, L.C.; Kahn, C.R. Phosphoinositide 3-kinase regulatory subunit p85alpha suppresses insulin action via positive regulation of PTEN. Proc. Natl. Acad. Sci. USA 2006, 103, 12093-12097. [CrossRef] [PubMed]

106. Taniguchi, C.M.; Winnay, J.; Kondo, T.; Bronson, R.T.; Guimaraes, A.R.; Aleman, J.O.; Luo, J.; Stephanopoulos, G.; Weissleder, R.; Cantley, L.C.; et al. The phosphoinositide 3-kinase regulatory subunit p85alpha can exert tumor suppressor properties through negative regulation of growth factor signaling. Cancer Res. 2010, 70, 5305-5315. [CrossRef]

107. Ueki, K.; Fruman, D.A.; Yballe, C.M.; Fasshauer, M.; Klein, J.; Asano, T.; Cantley, L.C.; Kahn, C.R. Positive and negative roles of p85 alpha and p85 beta regulatory subunits of phosphoinositide 3-kinase in insulin signaling. J. Biol. Chem. 2003, 278, 48453-48466. [CrossRef]

108. Yuan, T.L.; Cantley, L.C. PI3K pathway alterations in cancer: Variations on a theme. Oncogene 2008, 27, 5497-5510. [CrossRef]

109. Chagpar, R.B.; Links, P.H.; Pastor, M.C.; Furber, L.A.; Hawrysh, A.D.; Chamberlain, M.D.; Anderson, D.H. Direct positive regulation of PTEN by the p85 subunit of phosphatidylinositol 3-kinase. Proc. Natl. Acad. Sci. USA 2010, 107, 5471-5476. [CrossRef]

110. Rabinovsky, R.; Pochanard, P.; McNear, C.; Brachmann, S.M.; Duke-Cohan, J.S.; Garraway, L.A.; Sellers, W.R. p85 Associates with unphosphorylated PTEN and the PTEN-associated complex. Mol. Cell Biol. 2009, 29, 5377-5388. [CrossRef] 
111. Plotkin, B.; Kaidanovich, O.; Talior, I.; Eldar-Finkelman, H. Insulin mimetic action of synthetic phosphorylated peptide inhibitors of glycogen synthase kinase-3. J. Pharmacol. Exp. Ther. 2003, 305, 974-980. [CrossRef] [PubMed]

112. Jope, R.S.; Yuskaitis, C.J.; Beurel, E. Glycogen synthase kinase-3 (GSK3): Inflammation, diseases, and therapeutics. Neurochemical. Res. 2007, 32, 577-595. [CrossRef]

113. Rayasam, G.V.; Tulasi, V.K.; Sodhi, R.; Davis, J.A.; Ray, A. Glycogen synthase kinase 3: More than a namesake. Br. J. Pharmacol. 2009, 156, 885-898. [CrossRef]

114. Altman, B.J.; Stine, Z.E.; Dang, C.V. From Krebs to clinic: Glutamine metabolism to cancer therapy. Nat. Rev. Cancer 2016, 16, 619-634. [CrossRef] [PubMed]

115. Cluntun, A.A.; Lukey, M.J.; Cerione, R.A.; Locasale, J.W. Glutamine Metabolism in Cancer: Understanding the Heterogeneity. Trends Cancer 2017, 3, 169-180. [CrossRef]

116. Hensley, C.T.; Wasti, A.T.; DeBerardinis, R.J. Glutamine and cancer: Cell biology, physiology, and clinical opportunities. J. Clin. Investig. 2013, 123, 3678-3684. [CrossRef] [PubMed]

117. Mukhopadhyay, S.; Saqcena, M.; Foster, D.A. Synthetic lethality in KRas-driven cancer cells created by glutamine deprivation. Oncoscience 2015, 2, 807-808. [CrossRef] [PubMed]

118. Wang, H.; Zhao, R.; Guo, C.; Jiang, S.; Yang, J.; Xu, Y.; Liu, Y.; Fan, L.; Xiong, W.; Ma, J.; et al. Knockout of BRD7 results in impaired spermatogenesis and male infertility. Sci. Rep. 2016, 6, 21776. [CrossRef]

119. Xu, Y.; Cao, W.; Zhou, M.; Li, C.; Luo, Y.; Wang, H.; Zhao, R.; Jiang, S.; Yang, J.; Liu, Y.; et al. Inactivation of BRD7 results in impaired cognitive behavior and reduced synaptic plasticity of the medial prefrontal cortex. Behav. Brain Res. 2015, 286, 1-10. [CrossRef]

120. Heffner, C.S.; Herbert Pratt, C.; Babiuk, R.P.; Sharma, Y.; Rockwood, S.F.; Donahue, L.R.; Eppig, J.T.; Murray, S.A. Supporting conditional mouse mutagenesis with a comprehensive cre characterization resource. Nat. Commun. 2012, 3, 1218. [CrossRef]

(C) 2020 by the authors. Licensee MDPI, Basel, Switzerland. This article is an open access article distributed under the terms and conditions of the Creative Commons Attribution (CC BY) license (http://creativecommons.org/licenses/by/4.0/). 